\title{
Alcoholic Beverage and Traffic Accidents: Impact of the Drunk-Driving Law in Severity and Mortality of Victims
}

\author{
${ }^{1}$ Ane KS Bonfim, ${ }^{2}$ Lilia de S Nogueira, ${ }^{3}$ Cristiane de A Domingues
}

\begin{abstract}
Objectives: To analyze the impact of the Drunk-Driving Law on the characteristics and severity of traffic accident victims and to identify risk factors for mortality before and after law enforcement.
\end{abstract}

Materials and methods: A retrospective, quantitative study that analyzed victims of traffic accidents attended at a hospital in São Paulo, Brazil, between 2006 and 2010, through the analysis of medical records. The Drunk-Driving Law was considered the time frame of this research, and the victims were distributed in two groups: Before the law (January 2006 to June 2008) and after the law (July 2008 to December 2010). Pearson chi-square, Mann-Whitney, and multiple logistic regression tests were used, with a significance level of $5 \%$.

Results: The sample consisted of 1,405 victims, the majority being males $(78.01 \%)$, with a mean age of 37.39 years. In the group comparison (before and after the Drunk-Driving Law), there was a significant difference related to the external cause, admission to the ICU, and discharge conditions. Factors associated with prelaw mortality were age, number of injured body regions, and New Injury Severity Score. The length of hospital stay and the Revised Trauma Score were considered as protective factors for this outcome. After the validity of the law, in addition to the variables described earlier, the head/ neck and abdomen regions most severely injured were added as risk factors for mortality.

Conclusion: The impact of the Drunk-Driving Law set a positive outcome in the survival of the victims. However, when it comes to the statistics and severity of the trauma, it is necessary to sustain the law with reinforcement of the inspection so that more lives are saved.

Clinical significance: The results of this study provide support to managers on the importance of sustaining the law and the need of implementing new trauma prevention strategies.

Keywords: Accidents, Alcoholic beverages, Law enforcement, Patient acuity, Retrospective study, Traffic.

How to cite this article: Bonfim AKS, Nogueira LS, Domingues CA. Alcoholic Beverage and Traffic Accidents: Impact of the Drunk-Driving Law in Severity and Mortality of Victims. Panam J Trauma Crit Care Emerg Surg 2017;6(1):17-24.

\footnotetext{
${ }^{1}$ Nurse and PhD Student, ${ }^{2,3}$ Professor

${ }^{1,2}$ Department of Medical-Surgical, School of Nursing, University of São Paulo, São Paulo, Brazil

${ }^{3}$ Coordenation Nursing Bachelor's Course, Faculdade das Américas, São Paulo, Brazil

Corresponding Author: Ane KS Bonfim, Nurse and PhD Student Department of Medical-Surgical, School of Nursing, University of São Paulo, São Paulo, Brazil, Phone: +5511980262584, e-mail: karol_aksb@hotmail.com
}

Source of support: The Foundation for Research Support of the State of São Paulo (FAPESP) for sponsoring this study.

Conflict of interest: None

\section{RESUMO}

Objetivo: analisar o impacto da "Lei Seca" nas características e gravidade das vítimas de acidentes de trânsito e identificar os fatores de risco para mortalidade antes e após a implantação da lei.

Materiais e Métodos: estudo retrospectivo, quantitativo que analisou vítimas de acidentes de trânsito atendidas em um hospital em São Paulo, Brasil, entre 2006 e 2010, por meio da análise de prontuários. A "Lei Seca" foi considerada marco temporal desta pesquisa, sendo que as vítimas foram distribuídas em dois grupos: antes (janeiro/2006 a junho/2008) e depois da lei (julho/2008 a dezembro/2010). Os testes QuiQuadrado de Pearson, Mann-Whitney e a regressão logística múltipla foram utilizados, com nível de significância de $5 \%$.

Resultados: A casuística foi composta por 1.405 vítimas, a maioria do sexo masculino (78,01\%), com idade média de 37,39 anos. Na comparação dos grupos (antes e após a Lei Seca), houve diferença significativa em relação à causa externa, admissão na Unidade de Terapia Intensiva e condição de saída hospitalar. Os fatores associados à mortalidade antes da lei foram idade, número de regiões corpóreas acometidas e New Injury Severity Score. O tempo de permanência hospitalar e o escore do Revised Trauma Score foram considerados fatores de proteção para este desfecho. Após a vigência da lei, além das variáveis descritas anteriormente, foram acrescidas as regiões cabeça/pescoço e abdome mais gravemente acometidas como fatores de risco para mortalidade.

Conclusões: O impacto da "Lei Seca" configurou saldo positivo na sobrevida das vítimas, mas frente às estatísticas e gravidade do trauma, faz-se necessário a continuidade da lei com fortalecimento da fiscalização quanto ao seu cumprimento para que mais vidas sejam salvas.

Contribuição Clínica: Os resultados deste estudo oferecem subsídios aos gestores sobre a importância da continuidade da lei e da necessidade de implantação de novas estratégias de prevenção do trauma.

Palavras-chave: Estudo retrospectivo; acidentes de trânsito; bebidas alcóolicas; executoriedade da lei; gravidade do paciente.

\section{INTRODUCTION}

The World Health Organization reveals that millions of people are killed each year from traffic accidents. Data are alarming: There are approximately 1.24 million deaths from traffic accidents in 182 countries worldwide per year. 
The World Health Organization also emphasizes that, if nothing is done, by 2020 there will be 1.9 million deaths from traffic accidents in the world. ${ }^{1}$

In Brazil, data from the Mortality Information System of the Ministry of Health reveal that external causes, recognized as accidents and violence, ${ }^{2}$ represent the third most frequent cause of death, a situation preceded only by diseases of the circulatory system and neoplasms. Considering the analysis of the data available in this system for the last 10 years, there was an increase of approximately $22.4 \%$ of deaths due to transportation accidents (36,611 in 2005 vs 44,823 in 2014). ${ }^{3}$

The Institute of Applied Economic Research evaluated the annual cost of traffic accidents on Brazilian highways, amounting to BRL 22 billion, which corresponds to $1.2 \%$ of the country's gross domestic product. ${ }^{4}$

The high cost for the care of the victims by traffic accidents is notorious, overloading the public coffers. In addition, mortality and temporary or permanent injuries resulting from the traumatic event remove the victims of the labor market. Most of them are young people, in the economically active age group, ${ }^{3}$ which directly impacts the increase in the Potential Years of Life Lost indicator. So, it is possible to observe the direct impact of these causes on the economy of a country. ${ }^{4-8}$

Every traffic accident is influenced by different factors, such as human behavior, public transportation, poor traffic engineering, and fleet growth. Regarding human behavior, it is worth noting the excessive consumption of alcohol, especially among young people, and its relation with traumatic events. ${ }^{9}$

Drivers with blood alcohol concentration $\geq 0.2 \mathrm{dg} / \mathrm{L}$ of blood progressively present deficits in the skills necessary for safe driving, such as neuromotor changes, decreased attention, false perception of speed, euphoria, and difficulty in distinguishing spatially distinct brightnesses, in addition to decreased reaction time and drowsiness, as well as worsening of vision and reflex performance as a whole. ${ }^{10,11}$

One research reveals that the more serious the automobile accident, the greater the involvement with alcohol consumption, with alcohol identified as the main culprit for $70 \%$ of fatalities. ${ }^{12}$

Therefore, drinking and driving is pointed out as one of the determining factors for the occurrence of traffic accidents. Faced with this problem, on June 19, 2008, Law No. 11,705, popularly known as "Lei Seca" (DrunkDriving Law), which amended the National Traffic Code, came into effect in Brazil. This law is intended to establish blood alcohol limit 0 (zero) to drivers and imposes more severe penalties to those who drive under the influence of alcohol. In addition, the law provides restrictions on the use, advertising, and sale of alcoholic beverages. ${ }^{13}$
It is possible to identify in the literature some studies that analyzed the impact of the Drunk-Driving Law on different variables, ${ }^{14,15}$ with emphasis on mortality. ${ }^{16,17}$ However, these studies investigated short periods of time that preceded and succeeded the law (maximum 1 year), and the severity of the trauma was not included.

It should be emphasized that the short period of coverage of the data may be a limitation of the studies, as it reflects a possible temporary change in the behavior of drivers considering the intense surveillance established shortly after law enforcement. In addition, the characterization of victims according to indicators of trauma severity and the identification of variables that interfere with mortality are necessary, since they allow tracing aspects related to the traumatic event itself, as well as to the care provided, creating subsidies to innovate and reinforce policies on prevention, traffic awareness, and quality of care.

In this sense, the objectives of this research are to analyze the impact of the Drunk-Driving Law on the characteristics and severity of traffic accident victims and to identify risk factors for mortality before and after the implementation of the law.

\section{MATERIALS AND METHODS}

This is a retrospective study, with a quantitative approach of the victims of traffic accidents admitted to the adult emergency room of a hospital, a reference center for trauma care located in the city of São Paulo, Brazil, between 2006 and 2010, through information from a database based on the analysis of patient records.

The following inclusion criteria were considered in the selection of victims: Age 14 years or over (patients younger than 14 years are managed in another unit of the institution), being a victim of a traffic accident [V01-V89 of Chapter XX of the International Statistical Classification of Diseases and Related Health Problems (ICD-10) $]^{2}$ and being admitted to the hospital within the first 24 hours of the traumatic event. Patients transferred from other hospitals were excluded from the series.

The Drunk-Driving Law was considered an important time frame in this study. For the distribution of victims, this period was categorized into before the Drunk-Driving Law (from January 2006 to June 2008) and after the DrunkDriving Law (from July 2008 to December 2010).

Other variables analyzed in the study included age, gender, external cause, length of hospitalization, admission to the ICU, discharge condition, trauma severity according to anatomic scores [Injury Severity Score (ISS) ${ }^{18}$ and New Injury Severity Score (NISS) ${ }^{19}$ ], physiological score [Revised Trauma Score (RTS) ${ }^{20}$, and mixed anatomical and physiological score [Trauma and Injury Severity Score (TRISS) ${ }^{21}$ ], as well as the most severely injured body region and the number of injured body regions. 
In the group comparison (before and after the DrunkDriving Law), Pearson's and Mann-Whitney chi-square tests were applied. Multiple logistic regression was used to identify the factors associated with mortality in the periods before and after the law. For the construction of the regression model, the "stepwise backward" method was used. To evaluate the accuracy of the logistic regression model, the confounding matrix with a 50\% cutoff was calculated for the predicted probability. The variance inflation factor (VIF) was applied to detect the possibility of multicollinearity of the variables that remained in the final model. A significance level of $5 \%$ was established for all analyses.

The research was conducted within ethical standards, and was approved by the Institution's Ethics and Research Committee (Report no. 714,000).

\section{RESULTS}

The sample consisted of 1,405 victims of traffic accidents admitted in the proposed period, with a higher frequency of males $(78.01 \%)$ and mean age of $37.39( \pm 16.76)$ years. The predominant external causes were traumatized pedestrians $(41.57 \%)$, followed by traffic accidents involving motorcyclists $(29.25 \%)$ and occupants of cars or trucks $(22.14 \%)$. The mean length of hospitalization was $12.77( \pm 20.46)$ days, and the majority of the victims $(57.08 \%)$ were admitted to the ICU. The mortality rate in this sample was $16.65 \%$.
The results presented in Table 1 show that there was a decrease in the number of hospital admissions in the analyzed periods: 732 victims were admitted before the Drunk-Driving Law (from January 2006 to June 2008) and 673 after the Drunk-Driving Law (July 2008 to December 2010). In the group comparison, there was a statistically significant difference related to the external cause $(p<0.001)$, admission to the ICU $(p=0.004)$, and discharge condition $(\mathrm{p}<0.001)$. After the implementation of the law, there was an increase in the number of traumatized motorcyclists and the need for intensive care and a reduction in the number of fatalities.

Table 2 shows that there was no statistically significant difference between the groups when it comes to the variables related to the severity of the trauma (ISS, NISS, RTS, and TRISS), as well as age, length of admission, and number of injured body regions.

Table 3 shows that the final logistic regression model included variables, such as age, number of injured body regions, and NISS as risk factors for mortality of victims of traffic accidents occurring before the implementation of the Drunk-Driving Law. The length of hospital stay and the RTS were considered as protective factors for this outcome. After the validity of the law, in addition to the variables described earlier, more severely injured head/ neck and abdomen regions were added as risk factors for mortality.

Table 1: Group comparison (victims of traffic accidents that occurred before and after the Drunk-Driving Law) according to nominal variables, São Paulo, Brazil, 2006-2010

\begin{tabular}{|c|c|c|c|}
\hline Variables & Before the Drunk-Driving Law $n(\%)$ & After the Drunk-Driving Law $n(\%)$ & $p^{a}$ \\
\hline \multicolumn{4}{|l|}{ Gender } \\
\hline Male & $561(76.64)$ & $535(79.49)$ & 0.197 \\
\hline Female & $171(23.36)$ & $138(20.51)$ & \\
\hline \multicolumn{4}{|l|}{ External cause } \\
\hline Pedestrian & $327(44.67)$ & 257 (38.19) & $<0.001$ \\
\hline Cyclist & $28(3.83)$ & $22(3.27)$ & \\
\hline Motorcyclist & $160(21.86)$ & $251(37.30)$ & \\
\hline Occupant of cars or trucks & $189(25.82)$ & $122(18.13)$ & \\
\hline Occupant of heavy-duty vehicle & $23(3.14)$ & $17(2.53)$ & \\
\hline Others & $5(0.68)$ & $4(0.59)$ & \\
\hline \multicolumn{4}{|l|}{ Most severely injured body region } \\
\hline Head/neck (yes) & $384(52.46)$ & $352(52.30)$ & 0.953 \\
\hline Face (yes) & $46(6.28)$ & $46(6.84)$ & 0.677 \\
\hline Thorax (yes) & $162(22.13)$ & $156(23.18)$ & 0.639 \\
\hline Abdomen (yes) & $99(13.52)$ & $77(11.44)$ & 0.239 \\
\hline Extremities (yes) & $170(23.22)$ & $168(24.96)$ & 0.446 \\
\hline External surface (yes) & $67(9.15)$ & $68(10.10)$ & 0.546 \\
\hline \multicolumn{4}{|l|}{ Admission to ICU } \\
\hline No & $341(46.58)$ & $262(38.93)$ & 0.004 \\
\hline Yes & $391(53.42)$ & $411(61.07)$ & \\
\hline \multicolumn{4}{|l|}{ Discharge condition } \\
\hline Survivor & $576(78.69)$ & $595(88.41)$ & $<0.001$ \\
\hline Nonsurvivor & $156(21.31)$ & 78 (11.59) & \\
\hline
\end{tabular}


Table 2: Group comparison (victims of traffic accidents that occurred before and after the Drunk-Driving Law) according to numeric variables, São Paulo, Brazil, 2006-2010

\begin{tabular}{llll}
\hline Variable & Before the Drunk-Driving Law mean (SD) & After the Drunk-Driving Law mean (SD) & $p^{\text {a }}$ \\
\hline Age & $37.96(17.09)$ & $36.80(16.40)$ & 0.265 \\
Number of injured body regions & $2.75(1.19)$ & $2.80(1.30)$ & 0.673 \\
ISS & $15.19(9.72)$ & $15.11(9.79)$ & 0.807 \\
NISS & $19.58(11.27)$ & $19.75(11.48)$ & 0.702 \\
RTS & $6.38(2.09)$ & $6.48(1.92)$ & 0.846 \\
TRISS & $0.87(0.25)$ & $0.87(0.24)$ & 0.838 \\
Length of hospital stay & $12.77(18.60)$ & $12.77(22.33)$ & 0.203 \\
\hline
\end{tabular}

${ }^{a}$ Mann-Whitney test; SD: Standard deviation

Table 3: Risk factors related to mortality before and after the Drunk-Driving Law, São Paulo, Brazil, 2006-2010

\begin{tabular}{|c|c|c|c|c|c|}
\hline \multirow[b]{2}{*}{ Variables } & \multicolumn{2}{|c|}{ Before the Drunk-Driving Law } & \multicolumn{3}{|c|}{ After the Drunk-Driving Law } \\
\hline & $\operatorname{Exp}(\beta)$ & $p^{a}$ & $\operatorname{Exp}(\beta)$ & $p^{\mathrm{b}}$ & VIF \\
\hline Age & 1.03 & $<0.001$ & 1.04 & 0.629 & 1.41 \\
\hline Number of injured body regions & 1.72 & $<0.001$ & 1.50 & 0.617 & 1.70 \\
\hline NISS & 1.08 & $<0.001$ & 1.05 & 0.477 & 1.90 \\
\hline Length of hospital stay & 0.93 & $<0.001$ & 0.87 & 0.135 & 1.37 \\
\hline RTS & 0.47 & $<0.001$ & 0.43 & 0.625 & 1.55 \\
\hline More severely injured body region: Head/neck & 0.29 & 0.104 & 4.37 & 0.009 & 1.63 \\
\hline More severely injured body region: Abdomen & 0.44 & 0.139 & 7.66 & 0.005 & 1.85 \\
\hline
\end{tabular}

aSignificant value of logistic regression; ${ }^{b}$ Significant value of interaction (before and after the Drunk-Driving Law)

Prior to the implementation of the Drunk-Driving Law, the increase of 1-year old, one point in the NISS, and one injured body region increased the chance of death at 3,8 , and $72 \%$ respectively. This chance decreased by $7 \%$ each day of hospitalization and by $53 \%$ at each point of RTS.

After the Drunk-Driving Law, the risk and protection factors remained the same without significant changes in the odds ratio. However, in this period, the most severely injured head/neck and abdomen was added as risk factor for mortality, which increased the chance of death at approximately four and seven times.

The confusion matrix showed a general prediction of the logistic regression model of $91.7 \%$, indicating good discriminatory capacity. In addition, VIF values showed that there was no collinearity among the variables that remained in the final model.

\section{DISCUSSION}

The evaluation of the impact of the Drunk-Driving Law on different outcomes was carried out by some Brazilian studies that identified predominant involvement of males ${ }^{8,14-17}$ and young people (mean age 35-40 years $)^{14,16,22}$ in traffic accidents. This corroborates the finding of this research and reinforces the characterization of the group at greater risk for this type of occurrence, who often assume dangerous attitudes, such as high-speed driving associated with alcohol consumption. ${ }^{8,16}$
In this investigation, there was a greater frequency of traumatized pedestrians (41.57\%) followed by motorcycle accidents $(29.25 \%)$, and this finding was also identified in another investigation. ${ }^{5}$ Considering the total number of accidents that occurred in 2012, two-thirds were represented by pedestrians, cyclists, and motorcyclists. ${ }^{3,5}$ Brazil ranks second in the number of deaths per inhabitant due to motorcycle accidents, with an estimated loss of 40 motorcyclists per day. ${ }^{5}$

Comparing the periods that preceded and succeeded the law regarding the external cause, a reduction in the number of occurrences in all categories was observed, except for traumatized motorcyclists, with a significant increase of approximately $57 \%$ in the number of victims in the succeeding period of the Drunk-Driving Law.

Some hypotheses related to this increase in motorcycle accidents can be established: Lack of protection, carelessness associated with speed, alcoholism, inadequate supervision, overwork, trauma kinematics, and even a significant increase in the motorcycle fleet that, according to the National Transit Department, grew approximately $230 \%$ between 2006 and 2014. ${ }^{23}$

In the period analyzed in this study, $57.08 \%$ of the victims of traffic accidents were admitted to the ICU, with an average of 12.77 days of hospitalization. The number of patients requiring intensive care was significantly different before and after the Drunk-Driving Law (53.42 vs $61.07 \%$ ), and this increase may have occurred due to a constant improvement in the initial care of severe victims 
in the prehospital and hospital settings, which enhances the chance of survival.

The research that compared the hospitalizations of victims of traffic accidents on the Unified Health System in Brazil in the two semesters of 2008 (before and after the Drunk-Driving Law) showed a drop of 23.8 and $43.0 \%$ respectively, in admissions and in the mean length of hospitalization in the second semester (after the law enforcement), and the authors hypothesized that these reductions were associated with less severe accidents. ${ }^{8}$ However, these findings related to the severity of the victims were not identified in this study.

In the present investigation, a significant reduction in the number of deaths of victims of traffic accidents was observed after the validity of the Drunk-Driving Law. However, controversies are identified in analyzing the impact of the law in this outcome. Some studies did not observe a reduction in mortality in the comparative period, ${ }^{14,22}$ while others find a significant impact of the law in reducing mortality. ${ }^{8,16}$ When it comes to different regions of the country, researchers observed a reduction in the number of deaths in specific localities. ${ }^{15,17}$

The decrease in mortality after the law was $12.9 \%$ in the analysis of autopsy reports in Rio de Janeiro ${ }^{16}$ and $13.6 \%$ when considering the hospital mortality rate in Brazil. ${ }^{8}$

Regarding the specific localities, research showed a drop in the mortality rate from 18.7/100,000 inhabitants to $17.3 / 100,000$ inhabitants $(7.4 \%)$ between 2007 and 2009. However, reduction of this rate was observed in only 20 (74.07\%) of the 27 Brazilian states. ${ }^{17}$

Research carried out in São Paulo on the spatial analysis of deaths due to traffic accidents between 2007 and 2009 in the 63 microregions of the state identified areas of improvement and worsening of mortality rates, with a maximum reduction of $21.2 \%$ and an increase of up to $41.4 \%$ in deaths due to traffic accidents. ${ }^{15}$

Authors have highlighted that such findings may be influenced by local conditions and characteristics of roads, number of highways, as well as different levels of inspection. ${ }^{8,15}$

In this study, factors associated with mortality before the Drunk-Driving Law were age, severity of trauma according to NISS, and number of injured body regions. Age as a risk factor for mortality may be associated with a decrease in the physiological reserve of the human being, characteristic of the aging process. This reduction impacts directly on the organic response to trauma. ${ }^{24}$

The NISS score and the number of injured body regions reflect the patient acuity, which impacts directly on the prognosis. The NISS estimates the overall severity of the trauma. It is obtained from the sum of the squares of the Abbreviated Injury Scale scores (the scale used to describe the injuries resulting from a trauma and to identify solely the severity of the injury) of the three most serious injuries, regardless of body region. The NISS score may range from 1 to 75 . The higher the score, the greater the severity of the trauma and, consequently, the greater the probability of death. ${ }^{19}$

The protective factors for mortality identified in this study before the Drunk-Driving Law were length of hospital stay and RTS. The timing of trauma victim deaths occurs at three periods or peaks: ${ }^{25}$ The first peak (50\%) comprises immediate deaths occurring within minutes of the trauma, usually caused by serious injuries and incompatible with life. The second peak $(30 \%)$ represents the early deaths that occur between the 1st and 4th hour after trauma, usually caused by internal or cranial hemorrhage, abdominal lesions, or multiple lesions with significant blood loss. The third peak (20\%) includes deaths that occur days or weeks after the traumatic event, mainly due to complications resulting from the prolonged hospitalization, such as sepsis or multiple organ dysfunction. ${ }^{25}$ Considering this temporal distribution, it was found that there is an inversely proportional correlation between the mortality rate and the length of hospital stay.

Revised Trauma Score ${ }^{20}$ is a physiological severity index that analyzes the components of the Glasgow Coma Scale, systolic blood pressure, and respiratory rate. It is calculated by the sum of the products resulting from the values attributed to its three components, multiplied by their respective weights. The higher the value, the lower the severity of the patient. Considering the RTS analysis, it was identified in this study that the index is a protective factor. In this sense, this finding reinforces the importance of gravity in the mortality of victims of traffic accidents, since the lower the RTS value, the greater the chance of death.

After the Drunk-Driving Law, in addition to the variables described above, the most severely injured head/ neck and abdomen regions were added as risk factors for mortality. This fact may be related to the increase in the number of motorcycle accidents after the law, victims who often present traumatic brain injury and blunt abdominal trauma due to events associated with high-impact kinematics and less driver protection.

Only one investigation was found in the literature that analyzed lesions according to the injured body region before and after the Drunk-Driving Law. According to it, the highest percentage of reduction corresponded to lower extremities $(31.8 \%)$, neck $(31.6 \%)$, and thorax $(31.1 \%),{ }^{8}$ thus reinforcing the lower influence of the law in the reduction of lesions in head and abdomen.

No Brazilian scientific studies were analyzed that covered the influence of the Drunk-Driving Law on the severity of traumatic injuries of victims of traffic 
accidents, so it is impossible to discuss further the findings of this research.

However, since the problem of traffic accidents is not an exclusively Brazilian reality, a study carried out in Canada in 2010 evaluated the benefits of traffic laws in the control of speeding and drunk drivers and identified that there was a reduction in fatal accidents $(21.0 \%)$ and hospitalizations $(8.0 \%)$ after the enforcement of more severe traffic laws. The authors reinforced the significant reduction (52\%) in fatal accidents associated with alcohol consumption. ${ }^{\text {? }}$

The World Health Organization reports that other countries show evidence that the implementation and monitoring of legal measures that regulate the alcohol/ traffic accidents binomial are effective in reducing the traumatic events. ${ }^{1}$

Considering that the external causes, in their entire spectrum of manifestations, are predictable and preventable to a greater or lesser degree ${ }^{26}$ the present study stresses the need of investments in the prevention of traffic accidents in the Brazilian context.

Most of the research that analyzed aspects of the DrunkDriving Law highlighted, in its conclusions or considerations, the importance of continuous monitoring of the compliance with the law, as well as the need of intensifying preventive measures. ${ }^{8,14-17}$ This reinforces the importance of studies that analyze such aspects, whose results will contribute to the improvement of prevention strategies and increase of the survival of victims of traffic accidents.

The present study has some limitations. The sample consisted of patients from a single institution, a reference center for the care of victims of trauma, which causes constraints to the generalization of results. In addition, the identification and quantification of blood alcohol levels were not analyzed. This is due to the nonrequirement of blood alcohol tests or pulmonary alveolar airway test (ethylometer) as established in the Brazilian Traffic Code. ${ }^{27}$ The Brazilian citizen has the right to refuse to perform tests aimed at identifying the concentration of alcohol per liter of blood based on the statement that every accused individual has the right not to produce evidence against himself. ${ }^{27}$ Given this legal support and the low number of alcohol tests performed at the institution, this variable was not analyzed in this study.

\section{CONCLUSION}

There was an increase in the number of traumatized motorcyclists and admissions to the ICU and a reduction in the number of fatalities after the implementation of the Drunk-Driving Law. In this period, factors associated with mortality included the variables identified before the law (age, number of injured body regions, NISS, length of hospital stay, and RTS), added by more severely injured head/neck and abdomen regions. The impact of the Drunk-Driving Law on the survival of the victims set a positive outcome. However, considering the statistics and severity of trauma, it is necessary to continue and implement new prevention strategies so that more lives can be saved.

\section{CLINICAL SIGNIFICANCE}

The results of this study provide support to managers on the importance of sustaining the law and the need of implementing new trauma prevention strategies.

\section{REFERENCES}

1. World Health Organization (WHO). Global status report on road safety 2015: supporting a decade of action. Geneva: World Health Organization; 2015.

2. Brazil. Ministry of Health. Datasus. ICD-10 - International Statistical Classification of Diseases and Health-Related Problems. External causes of morbidity and mortality [text on the Internet]. Brasilia; 2014 [cited 2014 Apr 20]. Available from: http://datasus.gov.br/cid10/v2008/cid10. htm.

3. Brazil Ministry of Health. Datasus. Health information. Mortality statistics. Deaths per occurrence per year of death according to Large Group ICD-10 [text on the Internet]. Brasilia; 2016 [cited 2016 Dec 14]. Available from: http://tabnet. datasus.gov.br/cgi/tabcgi.exe?sim/cnv/ext10uf.def.

4. Institute of Applied Economic Research (IPEA). Social and economic impacts of traffic accidents in urban agglomerations. Brasilia: IPEA/ANTP; 2006.

5. Waiselfisz, J.J. Mapa da Violência 2013: acidentes de trânsito e motocicletas. Rio de Janeiro: Cebela; 2013.

6. Pan American Health Organization. Helmets: a road safety manual for health managers and professionals. Brasilia: Pan American Health Organization; 2007.

7. Swearingen A, Ghaemmaghami V, Loftus T, Swearingen CJ, Salisbury H, Gerkin RD, Ferrara J. Extreme blood alcohol level is associated with increased resource use in trauma patients. Am Surg 2010 Jan;76(1):20-24.

8. Mello Jorge MHP, Koizumi MS. Acidentes de trânsito causando vítimas: possível reflexo da lei seca nas internações hospitalares. Rev Abramet 2009;27(2):16-25.

9. Pinho FMO, Martins CS, Almeida FP. Fatores de risco para acidentes de trânsito entre jovens. Rev Abramet 2013;30(1): 28-57.

10. Soibelman, M.; Luz Junior, R.; Diemen, I.V. Problemas relacionados ao consumo de álcool. $3^{\mathrm{a}}$ ed. Porto Alegre: Artmed; 2004;539-550.

11. Mello Jorge MHP, Adura FE. Álcool e direção veicular. Rev USP. 2013;(96):23-36.

12. Abreu AMM, Lima JMB, Silva LM. Alcoholemy levels and mortality by traffic accidents in the city of Rio de Janeiro. Esc Anna Nery 2007;11(4):575-580.

13. Brazil. Law No. 11,705, of June 19, 2008 provides for the consumption of alcoholic beverage by driver of a motor vehicle and makes other provisions. Brasilia; 2008. Available from: http://www.planalto.gov.br/ccivil_03/_ato2007-2010/2008/ lei/111705.htm. 
14. Oliveira APP, Abreu AMM, Paixão LAR, Faria VS. Possible impact by the "dry law" (Prohibition law) in attendance to victims of traffic accidents in an emergency unit. Esc Anna Nery 2013;17(1):54-59.

15. Nunes MN, Nascimento LFC. Spatial analysis of deaths due to traffic accidents, before and after the Brazilian Drinking and Driving Law, in micro-regions of the state of São Paulo, Brazil. Rev Assoc Med Bras 2012 Nov-Dec;58(6):685-690.

16. Abreu AMM, Jomar RT, Thomaz RGF, Guimarães RM, Lima JMB, Figueiro RFS. Impact of the Drink-driving law on mortality from traffic accidents. Rev enferm UERJ 2012 Jan/ Mar;20(1):21-56.

17. Malta DC, Filho MAS, Montenegro MMS, Mascarenhas MDM, Silva MMA, Lima CM, Neto OLM, Temporão JG, Penna GO. Mortality analysis of traffic accidents before and after Brazil's Dry Law, from 2007 to 2009. Epidemiol Rev Saúde 2010;19(4):317-328.

18. Baker SP, O'Neill B, Haddon W, Long WB. The injury severity score: a method for describing patients with multiple injuries and evaluating emergency care. J Trauma 1974 Mar;14(3):187-196.

19. Osler T, Baker SP, Long W. A modification of the injury severity score that both improves accuracy and simplifies scoring. J Trauma 1997;43(6):922-925.

20. Champion HR, Sacco WJ, Copes WS, Gann DS, Gennarelli TA, Flanagan ME. A revision of the trauma score. J Trauma 1989 May;29(5):623-629.
21. Boyd CR, Tolson MA, Copes WS. Evaluating trauma score: the TRISS method. J Trauma 1987 Apr;27(4):370-378.

22. Vieira ILV, Holz AR, Silva MV, Santos A, Sanceverino SL. Perfil da violência no trânsito após a promulgação da "Lei Seca" - relação entre direção e bebida alcoólica. Rev Enferm Cent O Min 2011;1(2):210-219.

23. Denatran. National Transit Department. [text on the Internet]. Brasília; 2015. Available from: http://www.denatran.gov.br/ frota.htm.

24. Parreira JG, Soldá SC, Perlingeiro JAG, Padovese CC, Karakhanian WZ, Assef JC. Análise comparativa das características do trauma entre pacientes idosos e não idosos. Rev Assoc Med Bras 2010;56(5):541-546.

25. Trunkey DD. Trauma accidental and intentional injuries account for more years of life lost in U.S. than cancer and heart disease. Among the prescribed remedies are improved preventive efforts, speedier surgery and further research. Sci Am 1983 Aug;249:28-35.

26. Mello Jorge MHP. By way of conclusion. Rev Saúde Pública 1997 Aug;31(supl 4):51-54.

27. Brazilian Traffic Code. Presidency of the Republic Civil House Sub-Office for Legal Affairs Law No. 9,503, dated September 23, 1997, establishing the Brazilian Traffic Code, Art. 277 (Drafting given by Law No. 12.760, of 2012). Available from: http://www.planalto.gov.br/ccivil_03/leis/L9503Compilado. htm. 


\section{Alcoholic Beverage and Traffic Accidents: Impact of the Drunk-Driving Law in Severity and Mortality of Victims}

Alcohol is a major contributor to preventable deaths due to trauma across the world. Alcohol consumption is accepted in most cultures and its participation in motor vehicle crashes is well recognized. Driving under the influence of alcohol has been the focus of many injury prevention strategies. Interesting Canadian data indicate that intoxication may be more prevalent in pedestrians hit by motor vehicles than among drivers of these vehicles.

In this number of the Journal we have a study by three nursing colleagues from São Paulo, Brazil. The study is on the long term effect of the "Lei Seca" (drink \& driving law) created on June 2008. The law established a zerotolerance policy to drinking and driving. Drivers were forbidden to have any alcoholic beverage before driving and if tested, the only acceptable alcohol blood level was zero for anyone conducting a motor vehicle. More important than creating a zero tolerance law for drivers was the fact that it was widely announced and disseminated to the public and strictly enforced by the police. My understanding is that the law may also have affected the sale of alcoholic beverages in restaurants along the main highways. The conjecture of the study, which is well founded, is that the number of intoxicated drivers reduced significantly after the law came into effect. The study included patients admitted to a single hospital in São Paulo for 2 years after the law came into effect (2008) and compared the results with the observations done over a 2-year period prior to 2008.

The main findings of the study coincide with others on the effect of the "Lei Seca" - most short term studies. The authors found that a law of zero tolerance to alcohol for motor vehicle drivers led to a significant drop in admission to the Intensive Care Unit and an improvement in survival of injured patients. In contrast to these observations is the finding that the only exception was among motorcyclists. For this group of injured patients, the number of admissions increased significantly.

If one accepts the idea that the "Lei Seca" reduced the number of intoxicated drivers, alternative explanations are needed to explain the rising number of motorcyclists, which is not alcohol. The authors argue that lack of helmet and other protective gear, aggressive driving behavior and other reasons could explain the contrasting increase among motorcyclists.

Thus in my opinion the study makes two very interesting observations. First is the suggestion that a law forbidding motor vehicle drivers from drinking has a measurable effect in reducing hospital admission and improving survival of injured patients. This effect can be measured over a 2-year period after law implementation. Second, that a single law, no matter how powerful, cannot address all the major risk factors leading to trauma (increased number of motorcycle victims over the same period). The study reminds me that as professionals that provide direct care for injured patients, that we should continue (and expand) the struggle to have laws and regulations (such as "Lei Seca") created and implemented since they benefit of our patients. We should advocate for laws that benefit our patients - arguably motorcyclists should be the focus in Brazil. 